\title{
Sequestering seawater on land: a water-based solution to
}

\section{global issues [version 1; peer review: 1 approved with}

\section{reservations, 1 not approved]}

\section{Stéphane Boyer ${ }^{1,2}$, Marie-Caroline Lefort ${ }^{1,2}$}

${ }^{1}$ Environmental and Animal Sciences, Unitec Institute of Technology, Auckland, New Zealand

2Bio-Protection Research Centre, Lincoln University, Lincoln, New Zealand

V1 First published: 13 May 2016, 5:889

https://doi.org/10.12688/f1000research.8739.1

Latest published: 25 Apr 2017, 5:889

https://doi.org/10.12688/f1000research.8739.2

\section{Abstract}

The 'surplus' of oceanic water generated by climate change offers an unprecedented opportunity to tackle a number of global issues through a very pragmatic process: shifting the excess water from the oceans onto the land. Here we propose that sea-level rise could be mitigated through the desalination of very large amounts of seawater in massive desalination plants. To efficiently mitigate sea-level rise, desalinized water could be stored on land in the form of crop, wetlands or new forests. Based on a US $\$ 500$ million price to build an individual mega desalination plant with current technology, the cost of controlling current sea-level rise through water desalination approaches US $\$ 23$ trillion. However, the economic, environmental and health benefits would also be immense and could contribute to addressing a number of global issues including sea-level rise, food security, biodiversity loss and climate change. Because these issues are intimately intertwined, responses should aim at addressing them all concurrently and at global scale.

\section{Keywords}

Biodiversity loss, Climate Change, Desalination, Food security, Sealevel rise, Sustainable Development Goals

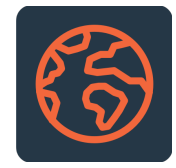

This article is included in the Climate gateway.

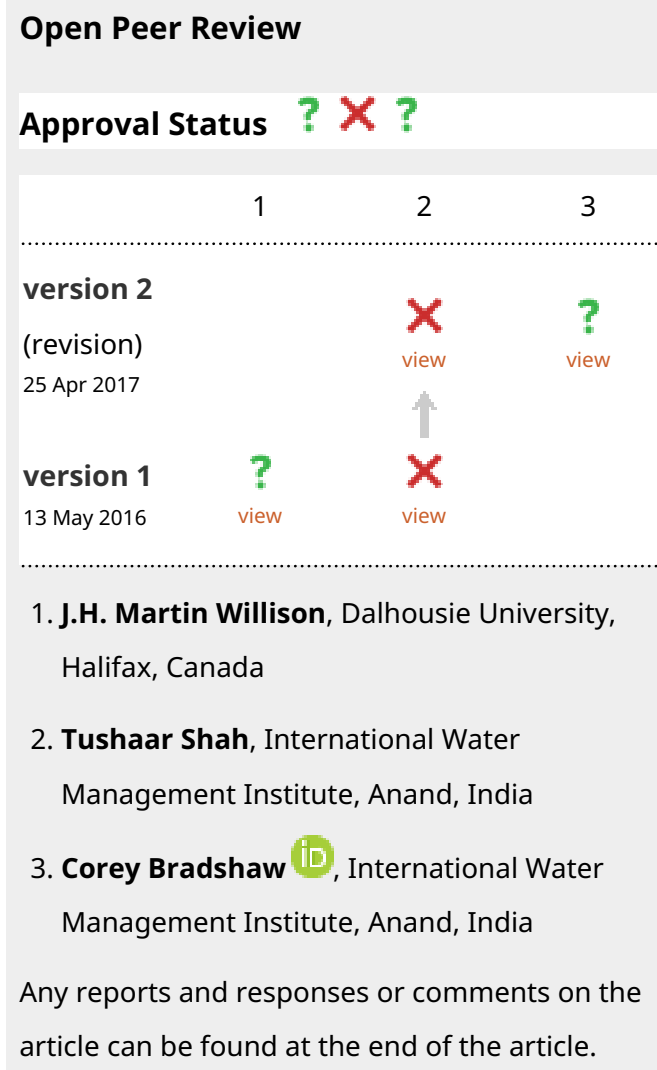

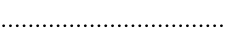

1. J.H. Martin Willison, Dalhousie University, Halifax, Canada

2. Tushaar Shah, International Water Management Institute, Anand, India

3. Corey Bradshaw ID, International Water Management Institute, Anand, India Any reports and responses or comments on the article can be found at the end of the article. 
Corresponding author: Stéphane Boyer (stephane.boyer@gmail.com)

Competing interests: No competing interests were disclosed.

Grant information: The author(s) declared that no grants were involved in supporting this work.

Copyright: $\odot 2016$ Boyer S and Lefort MC. This is an open access article distributed under the terms of the Creative Commons Attribution License, which permits unrestricted use, distribution, and reproduction in any medium, provided the original work is properly cited.

How to cite this article: Boyer S and Lefort MC. Sequestering seawater on land: a water-based solution to global issues [version 1; peer review: 1 approved with reservations, 1 not approved] F1000Research 2016, 5:889

https://doi.org/10.12688/f1000research.8739.1

First published: 13 May 2016, 5:889 https://doi.org/10.12688/f1000research.8739.1 


\section{Introduction}

Although the impacts of climate change on the oceans are 'harder to see than receding glaciers' ${ }^{1}$, the rise in sea-level and its economic and social consequences are already visible for people inhabiting low lying oceanic islands ${ }^{2}$. Seawater thermal expansion and the melting of glaciers and polar icecaps ${ }^{3,4}$ have led to an average sea-level rise of 3.2 [2.8 to 3.6] mm per year between 1993 and $2010^{5}$. Rising oceans cause coastal land to be lost or become inhabitable ${ }^{6}$ and will likely generate millions of "climate change migrants" ${ }^{7}$ as well as major economic and environmental damage in the near future ${ }^{1,8}$. However, this 'surplus' of water offers an unprecedented opportunity to tackle a number of global issues through a very pragmatic process: shifting the excess water from the oceans onto the land.

\section{Storing desalinized water}

Here we propose that sea-level rise could be mitigated through the desalination of very large amounts of seawater in massive desalination plants.
The resulting economic, environmental and health benefits would be considerable. Desalinized seawater can be used to grow crops in desertified and drought-prone areas ${ }^{9}$. This can directly contribute to increased food security in countries where water resources for agriculture are limited, by the reliable production of local food. Water is also needed to refill lakes and river systems dried up from human consumption and rising temperatures, as is already done for the Jordan River in Israel ${ }^{10}$. The second largest reserve of freshwater after polar icecaps, is groundwater, but its depletion in recent years due to increased water demand (mainly for agriculture) and to a very long recycling time ${ }^{11}$, is also contributing to sea-level rise ${ }^{12}$. Desalinized water could be used to counterbalance groundwater depletion and maintain current levels. To ensure longterm 'storage' on land, desalinized water could also be 'captured' in the form of restored wetland vegetation and novel forested areas. Wetlands provide essential ecosystem services, particularly relevant in a changing climate $^{13}$, but $87 \%$ of wetland areas have been lost since $1700 \mathrm{AD}^{14}$. Novel forests will not only capture and store water, they would also act as important carbon sinks (Figure 1),
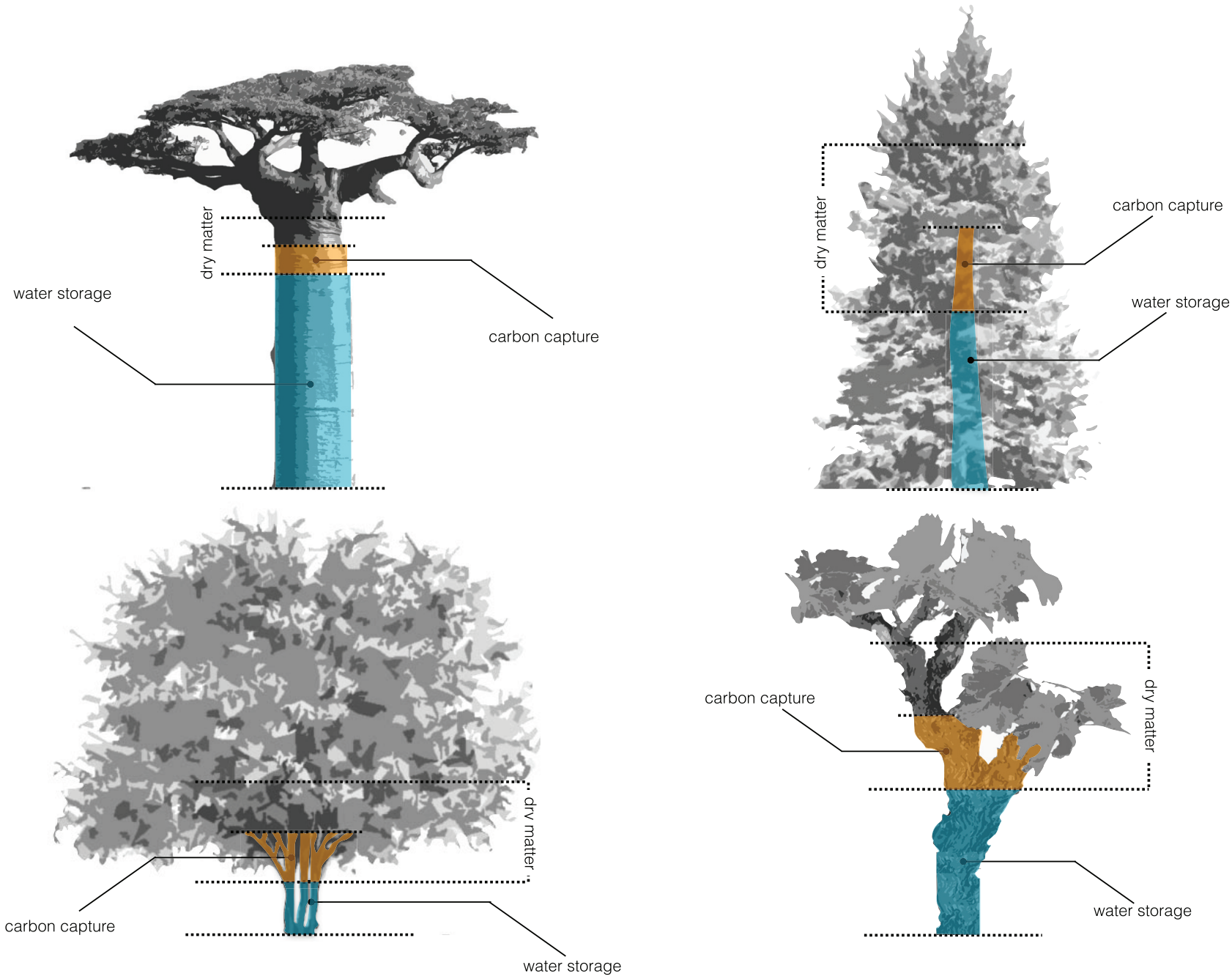

Figure 1. Schematic illustration of how excess atmospheric carbon and excess seawater could be captured in the trunk or stem of different woody species; clockwise: baobabs, douglas fir, vines and screwbean mesquite (data from 26-29). 
thereby supplementing existing forests, which may have reached saturation ${ }^{15}$, and mitigating climate change ${ }^{16}$. These restored or newly created habitats will also contribute to the conservation of particularly vulnerable and declining biodiversity ${ }^{14,17}$, thus tackling yet another major global issue.

\section{Desalinizing the excess seawater}

Today's desalination plants are designed mainly to produce potable water for human consumption, but also to support agricultural activities. As freshwater resources are becoming more unreliable in many parts of the world, the number and the size of these facilities are rapidly increasing. The Sorek desalination plant built in Israel in 2013 has reached full capacity in 2015 and is now producing up to $624,000 \mathrm{~m}^{3}$ of desalinized seawater per day, thereby providing potable water for $20 \%$ of Israeli households ${ }^{18}$. Although most of the 17,000 existing desalinization plants are smaller than the Israeli mega plant, globally 80 million $\mathrm{m}^{3}$ of seawater were processed per day in $2013^{19}$ and this figure was predicted to reach 97.5 million $\mathrm{m}^{3}$ in $2015^{20}$. Yet this is still a drop out of oceans that expand every year by $9-12$ trillion $\mathrm{m}^{3}$. To counteract such increase, 46,000 mega plants like the one in Israel would be required. With an individual price tag of US\$ 500 million, they would cost US\$ 23 trillion to build. However, technological advances and even bigger plants could significantly reduce this cost. The methodology used in Sorek and most modern desalination facilities is reverse osmosis ${ }^{20}$, where seawater is forced through semi-permeable membranes at 27 times atmospheric pressure to overcome the osmotic pressure of seawater ${ }^{21}$. To achieve this, reverse osmosis requires large amounts of energy. Therefore, an important area of research and innovation is the production of renewable energy such as solar, wind and tide-generated electricity to power desalination plants. Another important consideration is the fact that water used in agriculture does not require the same quality as drinking water ${ }^{22}$. As a consequence, desalination for agriculture purposes is technically less challenging and significantly cheaper ${ }^{23}$.

\section{Incentives to engage on the proposed path}

The projected acceleration of sea-level rise ${ }^{24}$ means that the desalinating capacity required for the proposed response is always increasing. A critical tipping point is the melting of Antarctica's ice shelves, which is projected to become irreversible if atmospheric warming exceeds 1.5 to 2 degrees Celsius above current temperatures ${ }^{4}$. This point could be reached in less than 50 years under the current emission scenario ${ }^{5}$. Given the timeframe required to deploy a worldwide array of massive desalination facilities, as well as the means and infrastructures to redistribute desalinized water where needed, it may not be achievable in the next 50 years. However benefits from engaging on the proposed path will be perceptible from the onset. The consequences of initiating the construction of massive desalination facilities will directly contribute to 9 of the United Nations' 17 Sustainable Development Goals ${ }^{25}$ (Figure 2). The progression to these positive outcomes is stepwise.

\section{Milestones}

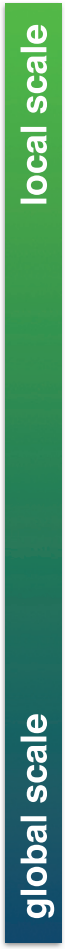

Building large for agriculture
Benefits desalination plants

Using desalinized water

Using desalinized water to restore wetlands and grow new forests

Storing enough water on land to mitigate SLR sustainable way
Will create jobs and infrastructure and foster innovation in the desalination process

Will allow cultivating desertified, infertile land and produce more food where most needed in a

Will enhance biodiversity in ecosystems that have been heavily disturbed, increase carbon capture and improve freshwater quality by natural filtration
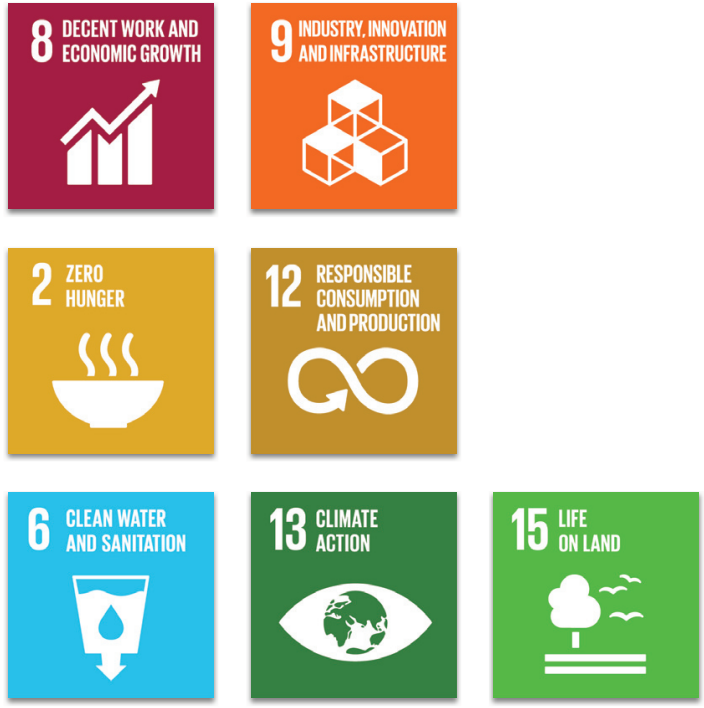

Will ensure the persistence of habitable conditions for ca. 200 million people living in coastal zones
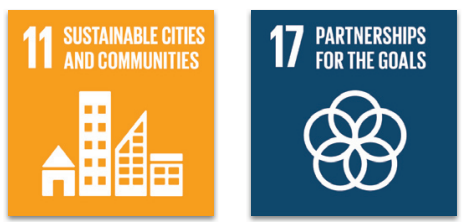

Figure 2. Milestones of the proposed sea-level rise mitigation strategy, direct benefits and how they relate to the United Nation Sustainable Development Goals (SDGs). 
At a local scale, these include the creation of jobs, the development of infrastructure, the driving of innovation in water treatment methods, and the possibility of increasing food production in famine-prone areas through the reliable and sustainable provision of water for agriculture. These outcomes should be seen as incentives to engage in the development of large-scale seawater desalination facilities, particularly in areas where freshwater availability is unreliable and food security is poor.

\section{Conclusion}

Although a radical option, the proposed strategy remains simple in principle, relies on existing and continuously improving technology and is scalable to mitigate sea-level rise and contribute to addressing a number of global issues including food security, climate change and biodiversity loss. Because these issues are intimately intertwined, solutions that only address one of them have a limited chance of success. There is a pressing need for proposing and testing more proactive and ambitious ways to address multiple global issues under one sole umbrella. The massive financial investment required to mitigate sea level rise through seawater desalination is likely to be largely balanced by socio-economic and environmental benefits. This perspective raises a number of critical questions relating to the financing and ownership of thousands of mega desalination plants around the world; the mechanism for distributing desalinised water to agriculture and other means; and the governance of such a global cooperation. The other major hurdle, is a global political plan to engage in a worldwide coordinated effort for mitigating sea-level rise.

\section{Author contributions}

S.B. developed the concept. S.B and M.-C.L. wrote the manuscript and prepared the figures.

\section{Competing interests}

No competing interests were disclosed.

\section{Grant information}

The author(s) declared that no grants were involved in supporting this work.
1. Allison $\mathrm{EH}$, Bassett HR: Climate change in the oceans: Human impacts and responses. Science. 2015; 350(6262): 778-82. PubMed Abstract | Publisher Full Text

2. McCubbin S, Smit B, Pearce T: Where does climate fit? Vulnerability to climate change in the context of multiple stressors in Funafuti, Tuvalu. Glob Environ Chang. [Internet]. Elsevier Ltd; 2015; 30: 43-55. Publisher Full Text

3. Wouters B, Martin-Español A, Helm V, et al:: Glacier mass loss. Dynamic thinning of glaciers on the Southern Antarctic Peninsula. Science. 2015; 348(6237): 899-903. PubMed Abstract | Publisher Full Text

4. Golledge NR, Kowalewski DE, Naish TR, et al:: The multi-millennial Antarctic commitment to future sea-level rise. Nature. 2015; 526(7573): 421-5. PubMed Abstract | Publisher Full Text

5. IPCC: Climate Change 2014: Synthesis Report. Contribution of Working Groups I, II and III to the Fifth Assessment Report of the Intergovernmenta Panel on Climate Change. IPCC. 2014; 151.

Reference Source

6. Popkin G: Breaking the Waves. Science. 2015; 350(6262): 756-9. PubMed Abstract | Publisher Full Text

7. Nicholls RJ, Hanson SE, Lowe JA, et al:: Sea-level scenarios for evaluating coastal impacts. WIREs Clim Chang. 2014; 5(1): 129-50. Publisher Full Text

8. Hinkel J, Lincke D, Vafeidis AT, et al:: Coastal flood damage and adaptation costs under 21st century sea-level rise. Proc Natl Acad Sci U S A. 2014; 111(9): 3292-7. PubMed Abstract | Publisher Full Text | Free Full Text

9. Burn S, Hoang M, Zarzo D, et al.: Desalination techniques - A review of the opportunities for desalination in agriculture. Desalination. [Internet]. Elsevier B.V.; 2015; 364: 2-16. Publisher Full Text

10. Bismuth C, Hansjürgens B, Yaari I: Technologies, Incentives and Cost Recovery: Is There an Israeli Role Model? In: Hüttl RF, Bens O, Bismuth C, Hoechstetter S, editors. Society - Water - Technology SE - 16 [Internet]. Cham: Springer International Publishing; 2016; 253-75. Publisher Full Text

11. Gleeson T, Befus KM, Jasechko S, et al.: The global volume and distribution of modern groundwater. Nat Geosci. 2016; 9: 161-167, In press. Publisher Full Text

12. Wada Y, Van Beek LPH, Sperna Weiland FC, et al:: Past and future contribution of global groundwater depletion to sea-level rise. Geophys Res Lett. 2012; 39(9): 1-6. Publisher Full Text
13. Costanza $R$, de Groot $R$, Sutton $P$, et al: Changes in the global value of ecosystem services. Glob Environ Chang. [Internet]. Elsevier Ltd; 2014; 26: 152-8. Publisher Full Text

14. Davidson N: How much wetland has the world lost? Long-term and recent trends in global wetland area. Mar Freshw Res. 2014; 65(1981): 934-41. Publisher Full Text

15. Hedin LO: Biogeochemistry: signs of saturation in the tropical carbon sink. Nature. 2015; 519(7543): 295-6.

PubMed Abstract | Publisher Full Text

16. Canadell JG, Raupach MR: Managing forests for climate change mitigation. Science. 2008; 320(5882): 1456-7. PubMed Abstract | Publisher Full Text

17. Newbold T, Hudson LN, Phillips HR, et al.: A global model of the response of tropical and sub-tropical forest biodiversity to anthropogenic pressures. Proc Biol Sci. 2014; 281(1792): pii: 20141371. PubMed Abstract | Publisher Full Text | Free Full Text

18. Technologies IDE: Sorek Project. [Internet]. 2015; [cited 2015 Nov 22]. Reference Source

19. Talbot D: Megascale Desalination The world's largest and cheapest reverseosmosis desalination plant is up and running. MIT Technology Review. 2016. Reference Source

20. Gude VG: Desalination and Sustainability - An Appraisal and Current Perspective. Water Res. [Internet]. Elsevier Ltd; 2016; 89: 87-106. PubMed Abstract | Publisher Full Text

21. Kim SJ, Ko SH, Kang KH, et al:: Direct seawater desalination by ion concentration polarization. Nat Nanotechnol. Nature Publishing Group; 2010; 5(4): 297-301. PubMed Abstract | Publisher Full Text

22. Quist-Jensen CA, Macedonio F, Drioli E: Membrane technology for water production in agriculture: Desalination and wastewater reuse. Desalination. 2015; 364: 17-32. Publisher Full Text

23. Zarzo D, Campos E, Terrero $\mathrm{P}$, et al.: Spanish experience in desalination for agriculture Spanish experience in desalination for agriculture. 2016; 3994(April): 52-66.

24. Watson CS, White NJ, Church JA, et al.: Unabated global mean sea-level rise over the satellite altimeter era. Nat Clim Chang. 2015; 5: 1-5. Publisher Full Text

25. United Nation: Resolution adopted by the General Assembly on 25 September 2015. 2015.

Reference Source 
Saito T, Yasuda H, Sakurai M, et al.: Monitoring of Stem Water Content of Native and Invasive Trees in Arid Environments Using GS3 Soil Moisture Sensors. Vadose Zo J. 2016; 15(3)

Publisher Full Text

27. Chapotin SM, Razanameharizaka JH, Holbrook NM: A biomechanical perspective on the role of large stem volume and high water content in baobab trees (Adansonia spp.; Bombacaceae). Am J Bot. 2006; 93(9): 1251-64. PubMed Abstract | Publisher Full Text
28.

Cermák J, Kucera J, Bauerle WL, et al.: Tree water storage and its diurnal dynamics related to sap flow and changes in stem volume in old-growth Douglas-fir trees. Tree Physiol. 2007; 27(2): 181-98.

PubMed Abstract | Publisher Full Text

29. Pire R, Ojeda M, Pereira A et al.: Extracción de N, P y K en tres cultivares de vid en la zona de el Tocuyo, estado Lara. (Removal of N, P and K in three grape cultivars in El Tocuyo, Lara state, Venezuela.). Rev Fac Agron (LUZ). 2001; 18: 201-16.

Reference Source 


\section{Open Peer Review}

\section{Current Peer Review Status: ? X}

Version 1

Reviewer Report 23 January 2017

https://doi.org/10.5256/f1000research.9403.r14081

(C) 2017 Shah T. This is an open access peer review report distributed under the terms of the Creative Commons Attribution License, which permits unrestricted use, distribution, and reproduction in any medium, provided the original work is properly cited.

\section{Tushaar Shah}

IWMI-TATA Water Policy Research Program, International Water Management Institute, Anand, Gujarat, India

Title and Abstract: The main title is fine; the sub-title "a water-based solution to global issues' is vague; desalination of sea water is the central argument of the article and should appear in the title somewhere.

Article Content: The article proposes a bold, nay sensational, solution to the potential consequences of seawater rise due to global warming. The proposal to the humankind is: begin by investing US $\$ 23$ trillion in building 46,000 mega desalination plants to desalinate $9-12$ trillion $\mathrm{m}^{3}$ of sea water every year, and use it for agriculture, wetland restoration, groundwater recharge, afforestation and in general, meeting fresh water scarcity around the world. Once this threshold capacity is commissioned, build more desalination plants to take care of increased global warming as it accelerates thermal expansion and further seawater rise. Doing this would protect low-lying island nations and coastal communities globally although other threats from climate change and warming will still challenge the humankind.

I would have normally thought the proposal bizarre, even reckless. But global warming and sea water rise are formidable and complex challenges and the world needs to be receptive to all manner of ideas, even if they sound bizarre. I would have thought that a policy proposal of such gigantic economic and ecological dimensions should be advanced with analytical effort of commensurate magnitude and depth; but this is missing in this analysis which I find a trifle casual in its approach. In fact, I am afraid the article has not subjected, to even a preliminary scrutiny, the various implications of its proposals using evidence freely available on the internet.

For example, there are important questions of technical feasibility that have not been touched, leave alone addressed. If fossil energy is to be used for desalination, how much will the 46,000 mega-desalination plants themselves contribute to further global warming and seawater rise (unless, of course, they all use solar or wind power)[1]? At a very conservative $5 \mathrm{kWh} / \mathrm{m}^{3}$ [2], producing 9-12 trillion $\mathrm{m}^{3}$ of desalinated sea water per year would use 45-60 trillion $\mathrm{kWh}$ of thermal energy every year, over two times the 22.7 trillion kWh of total electricity the world 
generated in 2012 [3]. The article provides no hint of how much more energy would be needed to transport desalinated water from plants to places of use, with what further impact on global warming? Given that the world's annual use of groundwater around 2010 was estimated at only 1.1 trillion $\mathrm{m}^{3}$ (Margat and van der Gun 2013 p.6), do depleted aquifers have empty storage to absorb a significant portion of the 9-12 trillion $\mathrm{m}^{3}$ that desalination plants will have to dispose of every year? Likewise, given that the world's total annual water withdrawals for all uses are of the order of 4 trillion $\mathrm{m}^{3}[4]$ is it possible for the earth to absorb 9-12 trillion desalinated sea water/year that will be made available from desalination plants on fields, forests and wetlands?

A redeeming aspect, the authors suggest, is that agricultural water use would not require removing all salts from seawater to make it drinking water quality and therefore will cost less money and energy. This is a dangerous proposal. Dumping 9-12 trillion $\mathrm{m}^{3}$ of partially desalinated seawater with say 10,000 ppm salts (compared to 35,000 ppm in sea water) could, over a decade or two salinize soils in the surface of the entire earth to the same level as the lower Indus basin in Pakistan, with frightening consequences.

Are there competing ideas/proposals for coping with sea water rise that we can compare the present proposal with? The authors are silent on this. Would it not be far cheaper to build levees around low-lying island nations to counter sea level rise? Might it be more cost effective to desilt the seas to expand their storage and use the silt to build the levees? Many geoengineering proposals are dismissed for being far less bizarre than the one proposed here; but injecting aerosols into the atmosphere to reflect sunlight away from the earth[5] would be far cheaper and a lot less riskier than 46,000 mega desalination plants and might resolve all problems of global warming than just seawater rise.

Would it be cheaper to live with those impacts or use the money saved to compensate people-atrisk from seawater rise? Climate Central estimated that worldwide 147-216 million people live on land that will be below sea level or regular flood levels by the end of the century, assuming emissions of heat-trapping gases continue on their current trend [6]. The Boyer-Lefort article proposes a one-time investment in building desalination plants at US $\$ 106,500-156,000$ per person-at-risk but glosses over US \$42,000-82,000/year per person-at-risk ever after in operational cost of desalinating sea water at US $\$ 1 / \mathrm{m}^{3}$ [7]. Would it take a lot more money to help these communities to make a transition to the Netherlands-type dykes-and-levee ecosystem to cope with rising sea level?

Developing countries have been, for over two decades, fighting hard to get the world to commit US $\$ 100$ billion in assistance to help them move to low-carbon technologies; but without any success. After all, US $\$ 100$ billion to protect the global carbon sinks is just 1 percent of the US $\$ 9$ 12 trillion the idea proposed here would cost. If this has not clicked, what would it take to persuade the world to invest $a$ third of its GDP (estimated in 2014 at US \$ 78 trillion [9]) in desalination plants to mitigate the impacts of sea level rise?

There are also other important questions about economic feasibility. Does this proposal compare well with other comparable proposals doing rounds? A 2014 report from World Energy Agency estimated that it would cost US \$ 44 trillion in investments, between now and 2050, for the world to change entirely to renewables and halt climate change and sea water rise all together [9]. A similar analysis by IPCC estimated the investments required to stabilize GHG levels in the atmosphere at US \$13 trillion. These clearly appear to be far better deals than the one proposed 
here since even after 46,000 mega desalination plants, most ill-effects of global warming, bar sea water rise, will continue to afflict the humankind.

Conclusion: Overall, even a cursory examination suggests that the proposal advanced is unrealistic, even disingenuous. I would have expected authors to undertake a modicum of scrutiny before offering their piece for publication. I do believe that its science is unacceptably poor.

References:

Margat, Jean and Jac van der Gun. 2013. Groundwater Around the World: A Geographic Synopsis, London: Taylor and Francis.

[1] Which authors hint at but make no effort to cost.

[2] https://en.wikipedia.org/wiki/Desalination

[3] https://en.wikipedia.org/wiki/World_energy_consumption

[4] http://www2.worldwater.org/data.html

[5] https://royalsociety.org/topics-policy/publications/2009/geoengineering-climate/

[6] http://www.climatecentral.org/news/new-analysis-global-exposure-to-sea-level-rise-flooding18066

[7] https://en.wikipedia.org/wiki/Desalination

[8] https://en.wikipedia.org/wiki/Gross_world_product

[9] https://www.technologyreview.com/s/527196/how-much-will-it-cost-to-solve-climate-change/

Competing Interests: No competing interests were disclosed.

I confirm that I have read this submission and believe that I have an appropriate level of expertise to state that I do not consider it to be of an acceptable scientific standard, for reasons outlined above.

Author Response 22 Apr 2017

\section{Stéphane Boyer}

The reviewer seems to have misread the paper on two important points.

First, the proposed strategy does not 'begin' by investing US $\$ 23$ trillion. We propose a gradual process where the building of desalination megaplants would obviously take many years. The figure of $\$ 23$ tn corresponds to the current price to build 46,000 
clones of the Sorek plant. This is only a conservative estimate of what it could cost. It is very unlikely that all plants will be exactly the same and it is very unlikely that their cost will remain the same through time.

Second, the paper does not mention the building of 'more desalination plants to take care of increased global warming'. We simply stress the fact that the building of the proposed plants would inevitably have a positive impact on the mitigation of global warming.

The original manuscript stated that 'an important area of research and innovation is the production of renewable energy such as solar, wind and tide-generated electricity to power desalination plants'. We have now developed this into a new subsection focusing on the main technical limitations of operating the proposed plants (i.e. energy consumption and environmental impacts). We also mention the issue around transportation with support form the literature.

The reviewer's concern about 'annual water withdrawal for all use' being limited to 4 trillion $\mathrm{m}^{3}$ makes little sense because we propose to store a large proportion of the water in forest, wetlands and as groundwater. On the latter, although the annual use of groundwater was 1.1 trillion $\mathrm{m}^{3}$ in 2010 , the renewing of this resource is very slow and as a result, the estimated global groundwater depletion during 1900-2008 alone was estimated to be 44.5 trillion $\mathrm{m}^{3}$ (Konikow 2011) and the rate of depletion likely increased after 2008.

Our statement about agriculture was that 'water used in agriculture does not require the same quality as drinking water' the reviewer's interpretation as 'dumping 9-12 trillion $\mathrm{m}^{3}$ of partially desalinated seawater with say 10,000 ppm salts' is quite a jump. An acceptable salinity for irrigation water is $<1600 \mathrm{ppm}$ of total dissolved solid as opposed to $400 \mathrm{ppm}$ for drinking water (Sarai Atab et al. 2016). We have now added this information to the manuscript.

This paper is meant to be an opinion, not a review. As such, we chose to focus on explaining what the core new idea is and discuss its implications rather than reviewing all other potential solutions, which have been published and discussed at length elsewhere. This is not the point of this manuscript. We also want to stress that the paper is limited in its length.

With regards to alternative solutions involving renewable energies. All recent simulations show that if the world changed entirely to renewable energies by 2050 , sea level rise will continue to rise, possibly for centuries due to sea-level rise commitment (Leverman et al. 2013), including the melting of antarctic sea shelves (Golledge et al. 2015). Even under the rather unlikely IMAGE 2.6 scenario, which includes very aggressive emissions reductions early in the 21 st century and deployment of negative emissions technologies later in the century to achieve radiative forcing of $2.6 \mathrm{w} / \mathrm{m}^{2}$ in 2100 , the reviewer's statement does not stand. Although $100 \%$ of renewable energy by 2050 would be a prodigious achievement, it would cost more than the investment we propose ( $\$ 44$ vs $\$ 23 \mathrm{tn}$ ), and it would most certainly not 'halt climate change and sea water rise' as claimed by the reviewer. 
We do not claim to propose a silver bullet that would surpass all other solutions proposed to date. However, we believe storing desalinised seawater on land is a valuable solution and one that is worth exploring because

1. It is novel

2. It brings specific advantages that could be complementary to other solutions presented to date,

3. It can create a number of positive outcomes from its inception, even if the building of 46,000 Sorek-like plants is not achieved

4. It is easily reversible as opposed to other geoengineering solutions. If need be, the plants can simply be turned off.

5. As time goes by, our capacity to succeed is likely to increase (due to better performing and cheaper technology being developed)

6. It has the potential to be a long-term solution as opposed to the temporary storing of water as snow on the Antarctic proposed by Friedler et al. (2016) for example.

References cited in this response

Frieler K, Mengel M, Levermann A. Delaying future sea-level rise by storing water in Antarctica. Earth Syst Dyn. 2016;7(1):203-10.

Konikow LF. Contribution of global groundwater depletion since 1900 to sea-level rise. Geophys Res Lett. 2011;38(17):1-5

Levermann A, Clark PU, Marzeion B, Milne G a, Pollard D, Radic V, et al. The multimillennial sea-level commitment of global warming. Proc Natl Acad Sci [Internet]. 2013;110(34):13745-13750. Available from: http://www.ncbi.nlm.nih.gov/pubmed/23858443

Golledge NR, Kowalewski DE, Naish TR, Levy RH, Fogwill CJ, Gasson EGW. The multimillennial Antarctic commitment to future sea-level rise. Nature [Internet]. 2015;526(7573):421-5. Available from: http://www.nature.com/doifinder/10.1038/nature15706 Sarai Atab M, Smallbone AJ, Roskilly AP. An operational and economic study of a reverse osmosis desalination system for potable water and land irrigation. Desalination [Internet]. The Authors; 2016;397:174-84. Available from: http://dx.doi.org/10.1016/j.desal.2016.06.020

Competing Interests: No competing interests were disclosed.

Reviewer Report 25 August 2016

https://doi.org/10.5256/f1000research.9403.r15875

(c) 2016 Willison J. This is an open access peer review report distributed under the terms of the Creative Commons Attribution License, which permits unrestricted use, distribution, and reproduction in any medium, provided the original work is properly cited. 


\section{J.H. Martin Willison \\ School for Resource and Environmental Studies, Dalhousie University, Halifax, NS, Canada}

This is an interesting conceptual paper. It is well written and the concept is clearly outlined, but the analysis is very incomplete. In its current form, the paper is just a trial balloon floating off into the unknown. For example, the paper briefly refers to a desalination plant in Israel that uses reverse osmosis (RO) technology. The plant is described as the largest in the world, yet the reference used to support this statement is undated. I found other sources indicating that it is indeed a very large RO plant and does supply $20 \%$ of Israel's potable water, but may no longer be the largest in the world. Remarkably, the paper lacks reference to an even larger desalination plant in Saudi Arabia at Ras al Khair which uses both RO and distillation. About $50 \%$ of Saudi Arabia's potable water needs are supplied by desalination (mostly obtained by distillation) and desalinated water has long been used in Saudi Arabia for growing crops. A more thorough analysis of the concept would examine both cases.

Clearly, sea levels are rising due to addition of water and thermal expansion. Also clearly, water removed by desalination temporarily reduces sea levels by moving water from the ocean phase to various freshwater phases (such as groundwater, lakes, bottles, land plants, and so on). In addition, there will probably be an increase in the amount of water in atmospheric phases (cloud, etc.). Huge problems with this proposal are not addressed, however, and are mostly not acknowledged. Monetary cost is addressed, but this should be the least of our concerns.

Where would the excess salt go and what would be the effects of local increases in ocean salinity? How much energy is consumed in the desalination, brine management, and water distribution processes and how much of that is generated by burning fossil fuels? Manufacture, maintenance and operation of the desalination plants involves mining, metal processing, transport of materials, and so on. Will the removal of water by desalination compensate for the impact of those processes on the climate system, or will this 'solution' simply add to the problem by creating more sea level rise than is reduced by desalination? How would the water be moved from its ocean-side sources to places where it would be useful for plant growth? How much energy will that cost, and how much of it would be fossil-fuel derived? What are the potential agricultural and forest productivities? How would food be delivered from production site to market? Given that the Mediterranean basin is likely to be a suitable initial site (noting that desalination in Israel is identified as a prime example), what are the regional socio-political implications of such a huge project on this region? Where are the production sites and the markets in the Mediterranean basin model? Would such a large-scale project relieve or exacerbate socio-political tensions in the region? How does the potential for desalination in the Mediterranean basin region compare with the experience of desalination in the Red Sea basin?

Without a deeper analysis to answer the wide range of questions that this concept invites, I am left unconvinced that the concept could be beneficial. A better start might be to do a full environmental and socio-economic cost-benefit analysis of the large desalination plants in Israel and Saudi Arabia and try scaling up the costs and benefits of the concept from there.

Groundwater depletion is a serious global problem, but many of the places where this is happening are in the centres of large continents, far from any ocean. I suggest that moving water over long distances makes the concept unrealistic in full cost-benefit terms. Perhaps desalination 
could be used to create green corridors along routes of prevailing winds, and in that way help water to move further inland, but there is no hint of this large-scale geo-engineering idea in the paper, and I would anyway tend to dismiss it as not feasible without a detailed analysis of a specific site, such as the Arabian peninsula. Realistically, to make a difference at a global level, massive quantities of water would have to be desalinated and moved from the oceans towards the middle of large dry continents (Asia, Africa, Australia) using wholly renewable sources of energy. How much, how far, and at what environmental costs?

All in all, I think this paper is intellectually stimulating but too preliminary to be indexed as a scientific paper.

Competing Interests: No competing interests were disclosed.

\section{I confirm that I have read this submission and believe that I have an appropriate level of expertise to confirm that it is of an acceptable scientific standard, however I have significant reservations, as outlined above.}

Author Response 22 Apr 2017

\section{Stéphane Boyer}

Thanks for the review.

At the time of the original concept of the paper, Sorek was the biggest fully operational desalination plant. As pointed out by reviewer 1, another plant in Saudi Arabia: Ras al Khair is now the world's biggest in terms of quantity of water produced. We have modified the manuscript to also mention that plant. Because the cost of building Ras al Khair is about 14 times that of Sorek, the latter remains a more economic solution for the proposed idea. Therefore, we maintained the focus on the Sorek model. We also provide new references regarding the data for the Sorek plant (Faigon 2016).

We acknowledge that the proposed concept comes with a number of issues and not all of these are addressed in the paper. Our aim here is to propose a new potential solution to mitigate sea-level rise and foster new thinking in the scientific community.

Overall there will probably be no excess salt because the aim is, at best, to maintain the existing volume of water in the ocean. However there will be significant local increases in ocean salinity, which are likely to cause environmental issues. This is now discussed. The amount of energy needed to power a large desalination plant is considerable. Powering 46,000 of them may seem difficult to conceive at the moment, but this would only happen through time. Desalination plants that are built today for potable water consumption or to support agricultural activities are already turning towards renewable sources of energy (see citations in the revised manuscript: Caldera et al. 2016; Shahabi et al. 2014). There is no reason why this would not be the case for the proposed plants. Again, the idea is not to build 46,000 plants at once. It would be a gradual process. As time goes by, it is likely that the costs of building desalination plants will decrease, as for the cost of solar energy technologies over this past decade, while their capacity and the portion of energy from renewable sources will increase. 
For each plant, there should be careful considerations of sustainability and environmental issues just like it is the case for plants that are built today.

The aim of the paper is to propose a global solution. It is not to select sites or analyse the socio-political implications for a particular region. It is obvious that every country engaged in this effort would face very specific social, political, economic and geographic issues some of which may depend on when these countries engage in the process. It is for example therefore difficult to predict the socio-economic or political state of a particular country 5 , 10 or 20 years ahead. We don't think it is sensible to extrapolate a full environmental, socioeconomic, cost-benefit, geographic and political analysis of one region. For these reasons, the case study and extrapolation is really not the angle we want to take.

Competing Interests: No competing interests were disclosed.

The benefits of publishing with F1000Research:

- Your article is published within days, with no editorial bias

- You can publish traditional articles, null/negative results, case reports, data notes and more

- The peer review process is transparent and collaborative

- Your article is indexed in PubMed after passing peer review

- Dedicated customer support at every stage

For pre-submission enquiries, contact research@f1000.com 